\title{
$\nabla$
}

\section{Um outro "Quarto Poder": imprensa e compromisso político no Brasil}

\author{
Afonso de Albuquerque \\ Universidade Federal Fluminense
}

\section{Introdução}

"A eleição das reformas"; "Por que o Brasil desconfia dos políticos". Os títulos de capa das revistas Época e Veja, em suas edições imediatamente anteriores às eleições de 1998, constituem um bom ponto de partida para discutir a questão do papel político da imprensa no Brasil. O que estes títulos sugerem? À luz do debate atual sobre o tema poderiamos dizer que o título de Época sugere uma atitude francamente governista da revista. enquanto Veju reflete velhos preconceitos contra os políticos em geral e (se observarmos o corpo da matéria) contra os parlamentares em particular. E não estariamos errados. Entretanto, poderíamos encontrar outras lições nesses mesmos enunciados. Época e Veja não estão apenas se pronunciando a favor do governo, ou manifestando desconfiança com relação ao Congresso Nacional; elas estão também demarcando o espaço de uma competência especifica: o de fornecer uma interpretação "independente" da cena politica, transcendente $\mathrm{em}$ relação às perspectivas particulares dos agentes políticos envolvidos.

Logo, a questão que este artigo se propõe a explorar é: em que termos a imprensa brasileira define hoje o seu compromisso politico? Neste sentido, a tentação de se julgar o jornalismo brasileiro pelo modelo americano de "jornalismo independente" é grande. São frequentes as profissões de fé dos órgãos da grande imprensa nos valores basilares do jornalismo "independente" - objetividade, neutralidade, imparcialidade. compromisso com a verdade. com os fatos, com o interesse público - bem como também críticas à atuação desses mesmos órgãos, com base na sua incapacidade (ou desinteresse) em honrar esses mesmos principios. 
A referência ao modelo americano se prova ainda mais importante na medida em que, sob alguns aspectos, a imprensa brasileira se encontra hoje mais próxima dele do que jamais esteve. De um modo geral, os órgãos da grande imprensa brasileira são hoje muito mais independentes de partidos ou facções politicas do que no passado, comprometidos que estão com a lógica empresarial capitalista (Ortiz, 1988; Taschner, 1992). Além disso, a multiplicação de fóruns de debate profissional - como por exemplo a revista Imprensa, organizações voltadas para o media criticism como o Observatório da Imprensa e o Instituto Gutenberg - sugere ter havido nos últimos anos um significativo avanço na constituição de uma identidade profissional jornalística baseada numa ética do serviço público. Para além das suas conviç̧ões políticas particulares, pode-se identificar hoje, entre os jornalistas brasileiros, um acordo muito maior quanto ao papel que cabe à imprensa desempenhar na democracia do que havia em tempos passados. E, de alguma forma, este papel aponta na direção de uma teoria da imprensa como um "Quarto Poder".

De um modo geral, as comparações entre o modelo americano e o jornalismo brasileiro tendem a apelar para um argumento da "falta" a fim de explicar as especificidades do nosso jornalismo. Este argumento tem sido formulado com diferentes níveis de complexidade. Um exemplo pouco sofisticado do uso deste argumento é a acusação, frequentemente repetida, de que faltam aos jornalistas brasileiros o rigor, a seriedade e a competência dos seus colegas americanos. Uma variação deste enfoque é a sugestão de que a sociedade brasileira é, ela mesma, incoerente, e que isso afeta a imprensa: "Censura para as idéias dos outros e liberdade para as minhas parece ser o estranho conceito de liberdade de imprensa que permeia a sociedade brasileira de alto à baixo, da esquerda para a direita" (Silva, 1991:98; grifo nosso).

Seja como for, o argumento da "falta" não é capaz de dar conta do problema em toda a sua complexidade: ele permite apontar diferenças entre o jornalismo brasileiro e o americano, mas não permite definir quais são as características específicamente "brasileiras" do nosso jornalismo. De modo explícito ou implícito, intencionalmente ou não, este modelo consolida uma perspectiva estrangeira sobre o jornalismo brasileiro, que "naturaliza" o modelo americano e "exotiza" o brasileiro. A premissa é de que, ao menos em princípio, o jornalismo brasileiro deveria ser semelhante ao americano. A questão que cabe explicar é por que isso não se dá.

Neste artigo, desenvolvo uma linha de argumentação diferente. A 
premissa adotada aqui é que os jornalismos que se praticam no Brasil e nos Estados Unidos são o fruto de ambientes culturais - e também, poder-se-ia acrescentar, políticos, econômicos e legais - completamente diferentes e, por este motivo, não há nenhuma razão a priori para supor que eles devessem ser semelhantes. Ao contrário, a questão que cabe explicar é a própria apropriação do modelo de jornalismo "independente" americano pelos jornalistas brasileiros: por que ela se dá e de que maneira isso acontece? A hipótese explorada aqui é que, por mais sincera que seja a adesão dos jornalistas brasileiros aos princípios basilares do jornalismo "independente", ela é antes de tudo um gesto formal; na prática, os jornalistas brasileiros tendem a interpretar esses princípios e a definir o seu compromisso político de maneira muito diferente dos seus colegas americanos.

O desenvolvimento do jornalismo "independente" nos Estados Unidos seria implausível na ausência de uma cultura marcadamente individualista e de um conjunto sólido de instituições políticas nela baseadas (Tocqueville, 1977). Tais elementos fundamentam não apenas a defesa da autonomia da imprensa em relação ao governo (com base no respeito ao direito à liberdade de expressão), como também o compromisso da imprensa com o interesse público (Nerone, 1993), muitas vezes descrito como se estabelecendo nos termos de um "Quarto Poder". O exercício deste "Quarto Poder" não se dá no âmbito do Estado e não se confunde com as prerrogativas dos três poderes constitucionais. Ele se exerce, ao invés, pela publicização dos problemas políticos para o conjunto da sociedade. Mais precisamente, ele implica no compromisso da imprensa com a objetividade no tratamento das notícias (Schudson, 1978; Soloski, 1993), com a representação do cidadão comum frente ao Estado (Hallin \& Mancini, 1984) e com o funcionamento eficiente do sistema de divisão de poderes (Cook, 1998).

O individualismo também é um traço componente da cultura brasileira, mas com um arranjo diverso e uma influência significativamente menor que na cultura americana. Os traços individualistas da nossa cultura convivem com (e são em larga medida subordinados) a princípios que traduzem uma preocupação avassaladora com a ordem e a "harmonia social" (DaMatta, 1979), e cuja lógica é, para usar os termos de Louis Dumont (1966, 1985), "holista" e "hierárquica". Inspiradas no exemplo das "nações civilizadas do mundo" (os Estados Unidos e os paises da Europa Ocidental) as instituições políticas e legais brasileiras frequentemente entram em choque com valores arrai- 
gados na cultura brasileira (Barbosa, 1996; Kant de Lima, 1994). Uma coisa, porém, é dizer que há contradições entre princípios básicos da vida social brasileira; e outra inteiramente diferente é que a contradição entre eles basta para definir a questão. No Brasil, os princípios e instituições "individualistas" tendem a ser incorporados com um sentido frequentemente diferente daquele que possuem nas "nações civilizadas", de tal modo que, na prática, se estabelecem compromissos entre eles e os princípios "holísticos" e "hierárquicos" da cultura brasileira (DaMatta, 1979, 1997; Barbosa, 1992).

A título de exemplo, podemos propor o seguinte raciocínio: o princípio "democracia", que em outras sociedades é entendido como diretamente derivado do direito da participação do indivíduo nos negócios do Estado, tende a ser associado, no Brasil, ao valor "ordem pública" - democracia é algo que interessa a todos - e entendido como uma conquista importante, ainda que instável, da nossa sociedade. Aceitas tais premissas, não é absurdo sustentar a idéia de que, em situações críticas, é legítimo sacrificar os direitos individuais em nome da preservação da democracia, a qual, afinal, é do interesse de todos. E, se se acredita que a democracia é uma conquista instável (e, portanto, a crise é uma constante) faz sentido tolerar sacrificios repetidos e sistemáticos do direito individual se eles se fazem em favor do bem comum.

Nessas condições, seria espantoso se a imprensa brasileira definisse o seu compromisso com a democracia em termos semelhantes à sua correspondente americana: em parte porque o principio da liberdade de expressão está longe de ter o status privilegiado de que desfruta nos Estados Unidos e, em consequência, a imprensa brasileira é potencialmente muito mais sujeita à censura política, formal ou infor$\mathrm{mal}^{2}$, que a americana; em parte porque a imprensa brasileira encontra muito mais incentivos para intervir diretamente na vida política e legal do país, influenciando as instituições a atuarem na direção "certa", do bem comum.

Tudo isso nos leva a supor que a concepção de "Quarto Poder" adotada pela imprensa brasileira é necessariamente muito distinta daquela que vigora nos Estados Unidos. O compromisso com a objetividade e a imparcialidade jornalísticas, com a representação dos cidadãos frente ao Estado e com a manutenção do equilíbrio entre os três poderes tendem, no Brasil, a ser interpretados em termos muito menos dogmáticos que nos Estados Unidos. Neste artigo, defendo a idéia de 
que. em alguma medida, se pode identificar neste modelo de "Quarto Poder" a idéia de um "Poder Moderador".

$\mathrm{O}$ argumento desenvolvido neste artigo se desdobra em quatro etapas: a primeira compara, de modo genérico, a cultura politica brasileira à americana; a segunda relaciona o modelo de jornalismo "independente" americano às características do ambiente cultural no qual ele se originou: a terceira esboça una comparação semelhante acerca do jornalismo brasilciro e seu contexto cultural: e a quarta disserta especilicamente sobre o modo como a imprensa se relaciona com o sistema de divisão de poderes e com os três poderes constitucionais no Brasil. Dada a escassez de trabalhos brasileiros acerca da dimensão social/cultural da noticia, as observações desenvolvidas nas duas últimas partes deste artigo devem ser julgadas pelo que são: um esforço exploratório antes que conclusivo acerca do assunto.

\section{Individualismo e cultura politica: Brasil e Estados Unidos}

O termo "individualismo" é usado aqui para designar um modelo de organização social no qual os indivíduos. iguais em seus direitos e dotados de interesses particulares, se associam voluntariamente uns aos outros para constituirem os grupos sociais. Entendido nestes termos. o individualismo constitui um traço importante das culturas politicas brasileira e americana, embora desempenhe um papel muito mais central nesta última do que na primeira.

Diferentemente de outros países, nos quais o desenvolvimento de princípios ou instituições individualistas tem dependido largamente da influência ou pressão estrangeiras. nos Estados Unidos o compromisso com esses principios e instituições se confunde com a sua própria origem e constitui um traço importante da identidade nacional (Tocqueville, 1977). Por este motivo, tem sido frequentemente observada a existência, nesse país, de um forte consenso em torno de um conjunto de valores fundamentais - a livre iniciativa, a soberania popular. a igualdade perante a lei. o respeito à liberdade de expressão e de culto - bem como das instituições politicas criadas em conformidade com esses valores - a Constituição bicentenária, o sistema federativo. o sistema de divisão de poderes, os mecanismos de consulta popular, etc. O acordo existente a estc respcito é tão significativo que permitiu ao sociólogo Robert Bcllah descrever a relação que se estabelece entre os americanos e suas instituições nos termos de uma "religião civil", a qual, em última análise, atribui a soberania da nação à Deus e 
fornece "uma meta transcendente para o processo político" (Bellah, 1967: 4).

Um elemento particularmente importante da cultura política americana é a a recorrente preocupação manifestada quanto à possibilidade dos indivíduos virem a ter a sua liberdade ameaçada por instituições poderosas, em particular, pelo "grande governo". É este temor que está na base do sistema de divisão de poderes adotado nos Estados Unidos (e também, como veremos mais adiante, na importância que se atribui à imprensa no que concerne à defesa da democracia). Na sua versão americana, o objetivo da divisão de poderes não é tanto produzir três poderes independentes, em conflito entre si, mas sim poderes interdependentes através de um sistema de checks and balances. Neste sistema "há pouco o que um poder [branch] possa fazer sem a cooperação ativa e o apoio do outro" (Fisher, 1989: 136).

No Brasil, os princípios e instituições individualistas devem a sua existência à importação de modelos originados em outros países, em alguns casos sob pressão política e mesmo militar (a repressão à escravidão, "para inglês ver", é um dos melhores exemplos a este respeito). De um ponto de vista formal, as instituições políticas e jurídicas brasileiras parecem fundamentadas nos mesmos princípios individualistas e igualitários que servem de base às suas equivalentes americanas. Na prática, porém, esses princípios tendem a ser interpretados à luz de outros, que obedecem a uma lógica totalmente distinta.

O caso do direito é exemplar: no seu discurso explícito, a cultura jurídica brasileira vincula-se à tradição individualista e igualitarista americana, nos termos da qual os conflitos são entendidos como cumprindo um papel central na geração de uma ordem consensual; implicitamente, porém, ela apela para uma concepção totalmente distinta, que enxerga no Estado o "guardião de uma ordem natural ou divina a ser preservada e defendida a todo custo de quaisquer conflitos" (Kant de Lima, 1994: 87).

Originária de um ambiente cultural igualitário e contratualista, a noção de cidadania também ganha um novo significado em um ambiente em que o Estado é entendido como estando acima da sociedade e a desigualdade humana é aceita como um mal necessário: por um lado, ela é entendida como o produto da ação reguladora do Estado - o Estado empresta cidadania à população através da educação pública, das carteiras de identidade, etc; por outro, ao contrário de um denominador comum - uma consequência natural da igualdade de todos os individuos perante à lei - a cidadania contitui a fronteira que separa 
aqueles que estão acima dos que estão abaixo da lei (DaMatta, 1997). Ou, como o exprime brithantemente um provérbio do folclore político nacional: "aos amigos tudo, aos indiferentes nada, aos inimigos a lei".

Particularmente no que se refere à vida política, há pouco consenso no Brasil em torno de seus valores e instituições fundamentais. Mesmo um valor básico como a democracia está longe de obter um apoio maciço da população (Baquero, 1996). A sina da Constituição atual (1988) ilustra bem o problema: enquanto os representantes mais à esquerda se recusaram a assiná-la, grande parte dos setores que a patrocinaram, declaram que ela torna o país ingovernável e empenhamse em modificá-la inteiramente. Em 1993 um plebiscito permitiu aos eleitores escolher não apenas o sistema de governo - presidencialista ou parlamentarista - como também pela forma de governo - república ou monarquia - do pais (Miguel, 1996). Tais condições não constituem, por certo, um ambiente favorável à percepção de uma ordem política fundamentalmente estável. O espectro da crise da democracia está presente mesmo nos períodos mais estáveis.

Finalmente, uma última ordem de considerações refere-se ao modo como o problema da divisão dos poderes tem sido tradicionalmente considerado no Brasil. Aqui também ele se explica menos como o produto da preocupação com a defesa dos direitos individuais frente ao Estado que da importação de modelos "civilizados" do estrangeiro. Na prática, ele tem sido encarado pela cultura política brasileira menos como uma solução que como um problema, um convite à anarquia. Manter o sistema de divisão de poderes sob controle, de modo a evitar que as suas potencialidades desagregadoras venham à tona, tem sido um problema recorrente da engenharia política no Brasil.

A solução clássica, da Constituição de 1824 , foi acrescentar aos três poderes originais um quarto, o Poder Moderador, exercido pelo Imperador e encarregado de resolver conflitos entre o Executivo e o Legislativo. Dessa forma, buscava-se proporcionar uma aparência liberal e moderna a uma monarquia que, no essencial, permanecia baseada no poder absoluto do imperador (Faoro, 1979). Criado sob medida para os interesses de Pedro l, tal arranjo político demonstrou ter um invejável fôlego, resistindo até a proclamação da República, em 1889.

A existência legal do Poder Moderador não sobreviveu ao Império, mas referências nostálgicas a ele continuaram a ser feitas durante o período republicano. Em 1933, por exemplo, Borges de Medeiros pu- 
blicou um livro chamado O Poder Moderador na República Presidencial, em que defendia a necessidade da criação de um quarto poder do Estado - o poder moderador da República - a ser exercido por um presidente eleito e cujo papel seria "regular, coordenar e moderar a ação dos outros poderes públicos, assegurando-lhes a harmonia entre si, e o livre exercício de cada um, dentro dos limites constitucionais". (Medeiros, 1933: 67) Ainda em 1993, no plebiscito acerca da forma e sistema de governo, a defesa do poder moderador do rei foi adotada explicitamente pelos programas e spots monarquistas (Miguel, 1996).

O projeto constitucional de Borges de Medeiros jamais foi levado adiante e, no plebiscito de 1993, a alternativa monarquista foi fragorosamente derrotada. Entretanto, ainda que de modo não tão explícito, a idéia de que, ao menos no Brasil, o equilibrio dos três poderes e a ordem pública só poderiam ser preservados mediante a atuação de um quarto poder neutro, a-político, permaneceu influente neste século. Uma instituição em particular foi tradicionalmente associada a este papel: as forças armadas. Embora uma facção do exército tenha sido a autora do golpe de estado que originou a República (Carvalho, 1987, 1990; Castro 1995), as forças armadas não foram capazes de alcançar, durante a Primeira República, um grau de unidade que thes permitisse serem reconhecidas como um "poder moderador" (Coelho, 1976); por isso, é talvez mais adequado descrevê-las como um "poder desestabilizador" (Carvalho, 1977). Foi somente a partir da Revolução de 1930 que as forças armadas passaram a desempenhar um papel mais central na vida política brasileira (Coelho, 1976; Skidmore, 1996).

Protagonistas do golpe que pôs fim ao Estado Novo, as forças armadas se tornaram pela primeira vez, no período entre 1945 e 1964 , amplamente reconhecidas como guardiãs da democracia, e árbitros últimos das disputas constitucionais. Nesse período, elas foram inúmeras vezes chamadas a intervir na política de modo a restaurar a "ordem pública" e o fizeram algumas vezes, sempre restituindo o poder a alguma autoridade civil (Coelho, 1976; Skidmore, 1996). Essa lógica foi rompida pelo golpe de 1964, que instalou um regime militar que durou até 1985. Com o fim do regime militar, debaixo do repúdio da grande maioria da população, a concepção das forças armadas como um poder moderador certamente perdeu grande parte do seu sentido ${ }^{3}$.

Qual é a atualidade da idéia do "poder moderador" hoje? Posta de modo tão explícito, ela é, provavelmente, pouco influente. Até prova em contrário, nenhuma instituição tem obtido sucesso em reivindicar 
para si o papel constitucional (ou meta-constitucional) de arbitrar as disputas entre os três poderes. Contudo. dada a permanência de uma atitude ambigua em relação à divisão dos poderes - entendida como necessária, porém perigosa - continua justificar que se julgue a administração da relação entre os poderes uma questão central da responsabilidade politica ${ }^{4}$. $A$ hipótese deste arligo é que novas instituições passam a reivindicar esse papel. e que a imprensa é, dentre elas, uma das principais. Entretanto, a imprensa não o faz de modo tão explícito, atirmativo e, mesmo, consciente como o fizeram o imperador e o exército. O papel da imprensa não é constitucionalmente definido, nem conta ela com recursos materiais que the permita impor a sua vontade através da coaçâo física. Ao invés disso, a imprensa reivindica o papel de intérprete privilegiado da realidade. e o laz se referindo à tradição americana do Quarto Poder. O ponto é que, talvez, "Quarto Poder" tenha, no Brasil, um significado totalmente distinto que nos Estados Unidos.

\section{Jornalismo e compromisso político nos Estados Unidos}

$O$ advento do modelo do jomalismo "independente" nos Estados Unidos tem sido, classicamente, interpretado como derivado de um conjunto de circunstâncias favoráveis que se apresentaram neste país a partir da década de 1830 e deram origem a um novo tipo de imprensa. conhecido como penny press. Diferentemente dos scus antecessores, jornais caros. de estilo rebuscado e dirigidos a públicos restritos - comerciantes ou simpatizantes políticos - a penny press baseava a sua existência no mercado. Baratos e com grande circulação, tais jornais "vendiam noticias para um público genérico de leitores e vendiam este público para os anunciantes" (Schudson, 1978: 23). Tais caracteristicas não somente permitiram, mas incentivaram esses jornais a se definirem como politicamente independentes, comprometidos com os fatos e com a defesa do interesse público: sendo sustentados por uma massa de leitores anônimos, a sua sobrevivência financeira dependia da sua capacidade de atingir ao maior público possivel, independentemente das simpatias partidárias dos seus leitores.

Como toda teoria clássica, essa também tem sido objeto de interpretações revisionistas. Iohn Nerone (1993), por exemplo. sugere que o compromisso da imprensa americana com um ideal de serviço público antecede em muito a penny press. Na trilha de Thomas Jefferson e nos termos da ideologia do republicanismo (que influenciou enormemente os primeiros anos da nação independente) a imprensa livre 
foi considerada, nos Estados Unidos, como um antídoto contra a tirania. Imaginada como um meio inteiramente transparente, que permitiria aos cidadãos se engajarem em um debate público racional para além dos limites das relações face-a-face, a imprensa era, por isso mesmo, entendida como um recurso fundamental com que poderiam contar os cidadãos para se protegerem contra os abusos do Estado. Esta concepção da imprensa como pilar de uma comunicação democrática ajuda a explicar o enorme desenvolvimento experimentado pela imprensa americana nas décadas que se seguiram à independência - de 45 jornais no momento da independência para $200 \mathrm{em} 1800 \mathrm{e}$, daí, para cerca de 1.200 jornais em 1835. Na interpretação de Nerone, o advento da penny press, longe de proporcionar um incremento da ética do serviço público, foi correlata à partidarização da vida política americana, e patrocinou uma concepção da vida pública como um marketplace of ideas, segundo a qual interpretações diferentes da realidade deveriam concorrer pela atenção do público.

A interpretação de Nerone é mais atraente do que a de Schudson, ao menos do ponto de vista do argumento desenvolvido neste texto. Ao destacar a influência do fator "economia de mercado" para explicar o modelo de jornalismo "independente" americano, Schudson abre caminho para uma universalização indevida deste modelo, nos termos da qual a história do jornalismo americano se torna uma história-padrão, enquanto a dos demais países é regida pela lógica do desvio: o que interessa aí é entender a razão das diferenças existentes em relação ao modelo americano, e o porquê da sua existência. Nerone, por sua vez, expõe de modo mais claro a relação que se estabelece entre o modelo de jornalismo "independente" e algumas características muito particulares da cultura política americana. Deste ponto de vista, as diferenças existentes entre os modelos de jornalismo de outros países com relação ao americano são bastante justificáveis; o problema a explicar é por que, em alguns desses países, os jornalistas insistem em reivindicar um modelo de jornalismo originado em um contexto cultural tão diferente do seu e como, concretamente eles aplicam esse modelo.

Em face dessas observações, cabe agora relacionar aspectos da cultura política dos Estados Unidos com características particulares do modelo de jornalismo desenvolvido neste país. Sustento aqui que diversos traços do jornalismo "independente" podem ser melhor entendidos à luz da dimensão individualista da cultura política americana: a concepção da notícia como algo que diz respeito a protagonistas 
e acontecimentos individuais; a ênfase na autonomia do repórter individual na produção da notícia: a caracterização do cidadão comum como interlocutor privilegiado do jornalista c a descrição da relação que se estabelece entre eles nos termos da representação dos interesses do primeiro frente ao segundo; a atribuição ao jornalismo da responsabilidade pelo cxercício de um "quarto poder", entendido nos termos de um compromisso com o equilíbrio dos três poderes constitucionais. Antes, porém, consideraremos outras características do jornalismo americano - o compromisso com os fatos, com o interesse público c com a objetividade jornalística - derivadas não tanto do caráter individualista da cultura americana quanto do consenso existente na sociedade americana em tomo de um conjunto de valores básicos.

O desenvolvimento de um jornalismo "centrado em fatos" (Chalaby, 1996) só é viável na medida em que um amplo acordo em torno de verdades fundamentais permita pôr os valores entre parênteses, possibilitando, assim. distinguir os domínios do fato e da opinião (Gans, 1979). Delimitar a fronteira entre os dois dominios é um problema complicado, e os jomalistas lidam com ele apelando para parâmetros de julgamento do senso comunn: é justamente o caráter de "naturalidade" [offcourseness] inerente ao discurso do senso comum (Geertz, 1998; Campbell, 1991) que permite a eles apresentarem o seu relato "como uma descrição 'objetiva' da situação, uma história na qual os fatos parecem falar por si mesmos" (Glasser e Ettema, 1991: 218). Por outro lado, onde tal consenso não existe, a idéia de um jornalismo "centrado em fatos" fiequentemente enfrenta uma enorme resistência, considerada como ingenuidade ou hipocrisia (Chalaby. 1996).

A idéia de um compromisso da imprensa com o interesse público parece igualmente abusiva na ausência de um amplo acordo em torno de valores políticos básicos como o que existe nos Estados Unidos: em paises nos quais isso não ocorre, os jornalistas se apresentam como funcionários de partidos políticos ou partidários de causas particulares, mas não como representantes da sociedade como um todo (Hallin \& Mancini, 1984; Mancini, 1991; Chalaby, 1996). Nos Estados Unidos, o desenvolvimento de uma ética do serviço público na imprensa remete a sua origem à época da independência: nos termos do republicanismo, entendia-se que a liberdade somente poderia ser conservada através do exercício virtuoso e independente da cidadania, e caberia à imprensa desempenhar um papel fundamental neste sentido (Nerone, 1993). Na sua versão atual, a ética do serviço público 
vincula-se também ao triunfo, no bojo do movimento Progressivo, de uma concepção "administrativa" da política, nos termos da qual "o facciosismo podia ser evitado, o conflito ultrapassado e a politica transformada em técnica" (Schudson, 1982: 107). Se na interpretação do republicanismo, a imprensa é entendida como um meio de comunicação transparente que serve ao debate público, a concepção progressivista implica em um papel sensivelmente mais ativo para o jornalista: "Do mesmo modo que os progressivistas procuravam encarar a política como técnica, também os jornalistas se esforçavam por ver a reportagem como comentário político feito por analistas especializados" (Schudson, 1982: 107).

Os compromissos com os fatos e com o interesse público se conjugam, no jornalismo americano, no compromisso com a objetividade. A adoção da objetividade como ideal jornalístico implica em mais do que simplesmente a crença na necessidade de se distinguir fatos de valores. Trata-se de um processo de institucionalização do fato jornalístico, em função do qual uma declaração é considerada válida não simplesmente porque corresponde ao "que realmente aconteceu", mas porque "foi submetida a um conjunto de regras consideradas legítimas pela comunidade profissional" (Schudson, 1978: 7). Porém, diferentemente do que acontece entre os cientistas, médicos ou advogados, os jornalistas não dispõem de linguagem, método ou treinamento que lhes permitam reivindicar o status de especialistas acerca dos assuntos sobre os quais falam ou escrevem. Deriva daí que a construção da objetividade jornalística se faz menos através do emprego de teorias e métodos precisos, compartilhados pela comunidade profissional, que pelo uso de determinadas convenções narrativas - a ênfase em acontecimentos isolados, atores individuais e novidades, o lead e a estrutura da pirâmide invertida, a busca do equilíbrio na notícia (a apresentação dos "dois lados da questão"), o uso de uma narração em terceira pessoa (Tuchman, 1978, Schudson, 1982, Campbell, 1991) cujo principal propósito é sublinhar o caráter "realista" do texto noticioso, através do apagamento das suas marcas ficcionais.

Outros aspectos do modelo de jornalismo "independente" se relacionam mais diretamente com as características individualistas da cultura americana. O traço mais visível disso é a centralidade do papel que a noção de "indivíduo" desempenha na definição do que é notícia: a notícia por excelência refere-se aos indivíduos (de preferência indivíduos "conhecidos") e a atos individuais, antes que a atores coletivos ou tendências gerais (Gans, 1980). Mesmo os jornalistas 
investigativos, que tematizam problemas sociais abrangentes como a violência policial, o racismo ou a corrupção em instituições públicas, o fazem quase sempre tendo em vista episódios concretos, que permitam dar a eles uma dimensão "humana" (Ettema e Glasser. 1998). A influência da cultura individualista sobre o jornalismo americano se estende, porém, muito além dos critérios que permitem definir o que é notícia. Ela se estende também ao modo como os jornalistas representam a si mesmos e ao seu papel na vida política.

Em linhas gerais, as representações correntes da atividade jornalística nos Estados Unidos tendem a associá-la antes à ligura do repórter individual que às empresas noticiosas - mesmo se, na prática, a autonomia profissional dos jornalistas americanos seja sensivelmente menor que que a de seus colegas de outros paises, como a Alemanha por exemplo (Donsbach \& Patterson. 1992: Esser. 1998). O caso Watergate, em particular, consagrou o mito do jornalista como um herói solitário disposto a enfrentar instituições poderosas para descobrir a verdade, na melhor tradição das histórias de detelive (Schudson, 1993), e ajudou a legitimar um novo modelo de jornalista, no qual o "observador distanciado" se faz substituir por repórteres-detetives que são, em alguma medida, personagens das histórias que narram (Campbell, 1991). Por outro lado, observa-se também um aumento da autonomia interpretativa dos jornalistas em relação às instituições politicas e à própria empresa noticiosa (Hallin, 1994).

Não menos importante. os jornalistas americanos definem o seu interlocutor fundamental como sendo o cidadão comum, numa atitude frequentemente qualificada como "populista". Ao contrário de outros profissionais, eles não se dirigem primordialmente a uma comunidade de especialistas, mas a um público de leigos - eles atuam antes como mediadores entre o mundo dos especialistas e o dos leigos que como especialistas propriamente ditos (Campbell, 1991). Deste ponto de vista, a ausência de uma linguagem esotérica constitui não um fator de fraqueza. mas um fator de autoridade para o jornalista americano. na medida em que o permite ancorar o seu texto naquilo que o senso comum reconhece como "verdade". Essa atitude difere significativamente da de jornalistas de outros paises. Os jornalistas italianos, por exemplo, definem como seus interlocutores fundamentais as instituições que atuam na esfera pública - partidos políticos, Igreja e sindicatos, e não o cidadão comum e. por esse motivo, a tarefa de tornar a complexidade do mundo institucional inteligivel para o cidadão comum não é entendida por eles como prioritária: os jornalistas italianos 
se dirigem a "uma audiência presumida, ou seja, familiar com a linguagem e com os assuntos políticos" (Hallin e Mancini, 1984).

O jornalista americano não apenas se dirige ao homem comum, como também reivindica representá-lo politicamente de alguma maneira. Novamente, o contraste com o caso italiano é bastante ilustrativo. No jornalismo italiano, a própria idéia de "homem comum", desvinculado da referência às instituições do mundo político, é julgada pouco expressiva. Num sistema político "coalizacional", o jornalismo exerce fundamentalmente o papel de mediador entre as forças do governo e da oposição e entre os setores que compõem a coalizão governamental (Mancini, 1991). Em contraste, o jornalismo americano reivindica representar os interesses do "homem comum" frente ao Estado. Isso explica porque a palavra dos indivíduos "comuns" seja tão frequentemente reproduzida em citações dos jornais ou nos soundbites dos telenoticiários (Hallin e Mancini, 1984).

Uma última observação diz respeito ao modo como os jornalistas definem o seu compromisso com o sistema de divisão de poderes. Os meios noticiosos são atores centrais da vida política americana atual os demais atores políticos dependem enormemente deles não apenas no que concerne à disputa de espaço político, mas também para o próprio exercício do governo - mas este extraordinário poder, não é incondicional: ele tem como pré-condição o compromisso dos meios noticiosos com os protocolos da objetividade jornalística. Sendo assim, a medida da importância política da imprensa não é tanto a sua capacidade de influenciar o processo de tomada de decisões quanto o fato de que os demais agentes políticos devem se dobrar à sua lógica particular - do valor de noticiabilidade - para merecer a sua atenção (Cook, 1998). No que concerne especificamente ao sistema de divisão de poderes, a imprensa americana define o seu compromisso fundamental com o equilíbrio entre os poderes constitucionais, tido como uma barreira crucial contra a tirania. Entretanto, dado que a lógica da atuação dos três poderes não atende igualmente aos critérios de noticiabilidade dä imprensa, a cobertura tende a privilegiar aqueles que se aproximam mais dos seus parâmetros e, mesmo que de forma não intencional, redefine a relação entre os poderes em termos que favorecem o Executivo em relação ao Legislativo (Schudson, 1982; Hallin \& Mancini, 1984; Cook, 1998).

\section{Jornalismo e compromisso político no Brasil}

A análise da maneira como os jornalistas brasileiros definem o seu 
compromisso político é enormemente prejudicada pela ausência de uma bibliografia expressiva acerca do jornalismo no e do pais, pelo menos no que se refere a uma perspectiva sócio-antropológica. Por isso, as observações feitas aqui são necessariamente rudimentares e devem ser entendidas como hipóteses provisórias, a serem exploradas em pesquisas futuras. Para facilitar a leitura seguiremos a mesma ordem de apresentação de questões que adotamos no trecho acima.

Como vimos anteriormente, a cultura brasileira estabelece uma relação ambivalente com os princípios e instituições individualistas (em parte eles são considerados como evidências do caráter "civilizado" das sociedades que os adotam, por outra parte, eles são tomados como fundamentalmente "estrangeiros" e sua aplicação à realidade brasileira é tida como problemática) e que, no que concerne especificamente à política, isso se traduz em um grande desacordo em torno de questões essenciais. Diante disso, como se situa o jornalismo? É plausivel esperar que os jornalistas brasileiros assumam um compromisso com a busca dos fatos, a defesa do interesse público e a idéia da objetividade em termos semelhantes aos dos seus correspondentes americanos? Acredito que não.

A idéia de "fato" só faz sentido na medida em que existe um consenso (ou algo próximo disto) em torno de um amplo conjunto de verdades fundamentais. Onde tais condições não se aplicam, é mais adequado falar em interpretações da realidade - produzidas a partir de perspectivas particulares e interessadas - que em fatos. Em algumas sociedades - as democracias da Europa Ocidental constituem o meIhor exemplo a este respeito - a idéia de que a definição da realidade é um processo plural, que opõe interpretações distintas. é aceita com naturalidade, como una consequência da própria democracia, e da diversidade dos interesses que, nela, se fazem representar. Mesmo neste caso é necessário que alguns princípios fundamentais sejam amplamente aceitos: as regras do jogo democrático, o sistema partidário, etc. Nessas sociedades não há nenhum escândalo se o jornalismo adota uma perspectiva partidária acerca da realidade.

No Brasil, não existe um consenso tão abrangente como o que há nos Estados Unidos que justifique a naturalidade de um "jornalismo baseado em fatos"; também, não há um acordo em torno do valor da democracia e do sistema partidário, tal como o que existe nos países da Europa Ocidental, a ponto de legitimar um modelo de jornalismo partidário. O resultado é que ambos os modelos têm disputado o posto de modelo dominante no país. Em termos gerais, a afirmação expli- 
cita do jornalismo como a defesa ativa de causas políticas ao modo europeu tende a ser encontrada principalmente entre jornalistas situados mais à esquerda no espectro ideológico e, normalmente, mais afastados em cargos administrativos de destaque; enquanto o modelo de jornalismo "independente" americano tende a ser mais nítido nas grandes empresas jornalísticas, particularmente nos cargos de direção (Waisbord, 1996a). O que não quer dizer que, na prática, o jornalismo praticado por essas empresas se aproxima daquele propugnado pelo modelo americano: muito frequentemente, as grandes empresas jornalisticas adotam explicitamente a defesa de determinadas causas por exemplo, a defesa da Reforma do Estado - em nome do interesse geral da nação e, agindo dessa forma, reivindicam estar atuando numa posição "independente".

Como explicar essa aparente contradição? A chave, talvez, seja o modo como os jornalistas brasileiros entendem o seu compromisso com o interesse público. Vários estudiosos brasileiros têm qualificado a atitude da imprensa brasileira no período posterior ao regime militar como "adversária em relação à democracia" (Souza, 1988; Porto, 1996; Lima, 1997). Neste artigo, porém, pretendo explorar uma outra hipótese, segundo a qual a atuação da imprensa brasileira neste período se explicada menos pela sua hostilidade à democracia ou a alguma das suas instituições em particular - como, por exemplo, o Congresso Nacional - do que pelo seu compromisso - culturalmente fundamentado - com uma concepção da democracia como uma realidade ainda por se construir e que, simultaneamente, tem a sua existência ameaçada pela instabilidade inerente à nossa sociedade. Nesse contexto, em que a excepcionalidade parece ser a norma, leituras bastante heterodoxas do modelo de jornalismo independente americano podem parecer bastante justificáveis para aqueles que as adotam ${ }^{5}$.

Na medida em que a defesa da democracia é interpretada muito mais como a construção de um patrimônio comum ou a defesa de um bastião ameaçado do que como o puro e simples respeito às regras do jogo e à vontade popular, não parece tão contraditória a idéia de que o comando da operação deva caber a líderes qualificados, o que, no caso da imprensa brasileira, se traduz em parte pela noção de "formador de opinião". Ou, dito de modo cínico, a preservação da democracia é um assunto sério demais para ser deixado ao "acaso" das decisões populares; a responsabilidade pelo problema deve caber fundamentalmente, então, a elites qualificadas para lidar com ele. Não é de se espantar, portanto, que noções cuja origem remete ao jornalismo 
"independente" americano sejam utilizadas, no Brasil, com um sentido completamente diferente do da sua matriz. Ninguém melhor para exprimí-lo que Otávio Frias Filho, diretor da redação da Folha de $S$. Paulo, segundo o qual "o profissionalismo não surge por geração espontânea. Surge pelo esforço extraordinário de um pequeno grupo que forma outras pessoas, adota uma atitude exemplar, corrige, cobra, critica, modifica" (cit. in Silva, 1988: 96). Trata-se de uma observação particularmente interessante se considerarmos a observação de Carlos Eduardo Lins da Silva - ele próprio ex-braço-direito de Frias Filho na Folha - de que a "leitura do Manual de Redação deste jornal e dos estudos científicos que vêm sendo feitos a seu respeito mostram com clareza indiscutivel que se tem ali um caso de influência consciente, não-ocasional, do jornalismo americano sobre o brasileiro" (Silva, 1991: 86).

A indecisão acerca do estatuto dos "fatos" e do "interesse público" tem por consequência uma postura ambígua também no que se refere à própria noção de objetividade. O Manual de Redação da Folha de $S$. Paulo ilustra isto de modo particularmente claro. O verbete objetividade se inicia com a constatação de que não existe objetividade em jornalismo, mas logo em seguida complementa: "Isso não o [o jornalista] exime, porém, da obrigação de ser o mais objetivo possível" (Novo Manual da Redação - Folha de S. Paulo, 1992: 19).

Conforme vimos, a objetividade não é uma consequência direta da crença ingênua na possibilidade de se conhecer os fatos mas, ao contrário, implica na pressuposição de que eles só podem ser conhecidos na medida em que sejam submetidos a métodos institucionalizados de avaliação. É razoável supor, então, que a objetividade tenderá a se tornar um parâmetro tão mais importante para o jornalismo, quanto mais ela também o seja em outros campos da vida social. A este respeito é de grande valia a análise comparativa desenvolvida por Kant de Lima sobre os princípios e métodos que orientam a produção de verdades no Brasil e nos Estados Unidos. A título de exemplo, mencionarei aqui algumas questões referentes às diferenças das tradições jurídicas dos dois países.

Para resumir, o sistema americano do trial by jury se baseia numa representação da ordem pública como se constituindo através da resolução dos conflitos, seja através de acordos ou barganhas, seja através do veredito, que constrói uma verdade consensual através de um processo público ritualizado, dialógico e coletivo. Basicamente, o processo consiste numa negociação da culpa entre as partes. Sendo baseado 
no princípio individualista da defesa do cidadão contra abusos do Estado, este sistema se baseia na presunção da inocência do réu, cabendo à acusação provar ao júri a sua culpabilidade. Todas as evidências devem ser negociadas, e tudo o que é dito deve ser verdade. O sistema brasileiro da inquirição, por sua vez, se baseia em princípios totalmente distintos: o que está em jogo não é tanto a defesa dos direitos dos indivíduos quanto da ordem estabelecida - que o conflito e o crime parecem ameaçar. Neste contexto a idéia de que a produção da verdade seja uma tarefa que caiba primordialmente ao conjunto dos cidadãos e que possa ser negociada ao longo do processo soa absurda, e parte-se da presunção de que o réu é, ao menos potencialmente, culpado. O que se busca obter é uma verdade absoluta, e a confissão do réu é julgada o melhor meio para obtê-la. Dado que é em princípio culpado, espera-se que o réu minta em causa própria, e isto é legalmente permitido a ele; por outro lado, o objetivo do interrogatório é forçar ao réu a se confessar (e se arrepender) e o recurso a perguntas capciosas não constitui por isso um escândalo.

Mas afinal, o que isto tudo tem a ver com o nosso tema específico? Por ora basta dizer que o princípio da objetividade pressupõe a idéia de que os argumentos somente podem ser válidos na medida em que, com base em parâmetros pré-estabelecidos, sejam universalmente demonstráveis. O que implica em uma lógica fundamentalmente individualista e igualitária: através dos fatos, todos são iguais perante a verdade. Por outro lado, numa cultura, como a brasileira, que consagra a verdade como um assunto que diz respeito antes ao interesse coletivo que ao indivíduo, e que postula a desigualdade no acesso a ela como algo inevitável e necessário, o solo para o desenvolvimento de métodos e práticas baseados no princípio da objetividade não pode ser dos mais férteis. Nos termos de Kant de Lima: "Se aqui o argumento da autoridade, que pessoaliza e hierarquiza a orígem da citação, dá peso e importância diferenciados ao argumento, lá prevalece a autoridade do argumento, onde, magicamente, os fatos são considerados como que 'naturalmente' autodemonstráveis" (1994: 99). Como esperar, então, que o princípio da objetividade alcance no Brasil um desenvolvimento comparável ao do que tem nos Estados Unidos?

Um outro conjunto de observações diz respeito à aplicabilidade de princípios e práticas originadas de uma cultura fundamentalmente individualista como a americana em um contexto cultural totalmente distinto, o brasileiro. Os dados disponíveis são insuficientes para permitir a formulação de hipóteses consistentes sobre o peso que, no jor- 
nalismo brasileiro, têm os individuos e as ocorrências individuais como critérios de noticiabilidade. Na teoria, estes seriam critérios fundamentais de noticiabilidade também no Brasil. Resta definir de que maneira esta teoria é posta em prática.

Com relação à importância do repórter individual na mitologia do jornalismo brasileiro, há indicações mais nitidas de que ela é bem menor que nos Estados Unidos. A comparação da cobertura do caso Collor com Watergate é bastante ilustrativa a este respeito. Diferentemente de Watergate, no caso Collor não foram os repórteres individuais que receberam os créditos da cobertura do caso, mas as empresas noticiosas. Waisbord (1996b) observa que os editoriais dos semanários que cobriram o caso repetidamente acentua993 ram que a decisão de cobrir o caso representava a posição do semanário como um todo, e as cartas publicadas em Veja congratulavam sempre a revista ou a imprensa em geral, mas nunca o trabalho de repórteres individuais.

Duas questões estreitamente relacionadas dizem respeito a quem 0 jornalismo brasileiro considera o seu interlocutor fundamental, e que tipo de relação estabelece com ele. Acerca da primeira questão é razoável supor que, tendo adotado estilos narrativos próprios do modelo de jornalismo americano - o lead, a pirâmide invertida. o texto em estilo simples, a dramatização - o jornalismo brasileiro se dirija muito mais ao "cidadão comum" que às instituições representativas da vida política e social. Se o interlocutor a quem a imprensa se dirige é, aparentemente, o mesmo no Brasil e nos Estados Unidos o modo como essa interlocução se configura parece ser, porém, bastante distinto nos dois casos.

A relação que se estabelece. no Brasil, entre os jornalistas e as empresas jornalísticas de um lado, e os cidadãos "comuns" do outro, foge inteiramente aos parâmetros americanos da representação, pelos primeiros, dos interesses dos cidadãos frente às instituições e ao Estado. Eles clamam representar, antes os interesses coletivos, do país como um todo - por exemplo, "Veja: os olhos do Brasil". Em consequência, a imprensa brasilcira pode reivindicar (e o faz efetivamente) a defesa de causas do interesse geral da nação ainda que elas se confrontem com os interesses de vastos setores (e em alguns casos da maioria) da sociedade.

Diferentemente da imprensa americana. que define os seus fatos e a objetividade com referência a valores consensuais da sociedade (ou pelo menos julgados como tal), a imprensa brasileira define frequentemente o seu compromisso político como se fazendo no sentido de 
construir um consenso em torno de verdades que, embora evidentes, infelizmente parecem não o ser para uma parcela significativa da população. A diferença no modo como os jornalistas e empresas dos dois países concebem a sua missão pode ser explicada, ao menos parcialmente, como o resultado das diferentes maneiras como a ordem política é percebida nos dois países. Em um país em que a ordem política é percebida como fundamentalmente estável, como nos Estados Unidos, a responsabilidade política se apresenta como uma mera questão de seguir as regras do jogo; em um país na qual a ordem política é entendida como estando ainda por ser criada e/ou ameaçada de ser destruída, a responsabilidade política tende a ser entendida como uma questão mais delicada, de preservar as condições que permitem às regras do jogo vigorar, mesmo que ao preço do descumprimento de algumas (ou de várias) regras fundamentais.

Isso fica evidente, por exemplo, na estratégia de citação de fontes predominante no Brasil. Nos Estados Unidos, a apresentação dos "dois lados da questão" é um recurso crucial através do qual os jornalistas reivindicam sua objetividade quando lidam com questões polêmicas. Dessa maneira, é deixada ao público a responsabilidade por decidir qual das interpretações descritas é a mais correta (Tuchman, 1993). No Brasil, por sua vez, em que pese o compromisso formal das empresas noticiosas e dos jornalistas com o "equilíbrio" na apresentação das notícias, a seleção das fontes obedece a uma outra lógica: trata-se muito mais de ilustrar uma tese que de apresentar interpretações conflitantes acerca de um assunto. Isto é magnificamente ilustrado pelo seguinte depoimento, do jornalista Augusto Nunes:

"Como a Veja não tem editorial, editorializa o texto. Quando achava que determinadas frases nossas tornariam o texto editorializado demais, eu pegava um deputado, apresentava tal frase e pedia para atribuir a ele. Sempre com autorização do entrevistado, embora a autoria fosse da Veja" (apud Ribeiro, 1994: 101)

O que torna este depoimento tão extraordinário é o fato de ele não ter sido proferido por um jornalista dissidente ou renegado, mas por um nome importante do mainstream jornalístico brasileiro - ex-diretor de redação do Estado de São Paulo, colaborador frequente das versões televisiva e online do Observatório da Imprensa - e, não menos importante, pelo fato de se referir a práticas do mais importante semanário de informação brasileiro. É desnecessário dizer que o fato de tal declaração ter se tornado pública em nada abalou a carreira ou o prestígio profissional do seu autor e, muito menos, da revista Veja. 
Em outros casos, a defesa do engajamento ativo da imprensa na defesa de causas supostas como de intercsse geral é ainda mais explícita. Um excelente exemplo, a este respeito, é o artigo "Cabe à imprensa insistir na necessidade das reformas" (Aragão, 1998) publicado na revista Imprensa. Segundo ele, a imprensa brasileira não se limita ao papel de quarto poder, como em outros paises: "A imprensa no pais é formadora de políticas públicas. balizadora de parâmetros políticos, fiscalizadora do poder público. juiza do comportamento [...] e. sobretudo, controladora da agenda nacional". Por isso. caberia à imprensa "manter viva a prioridade do ajuste fiscal na agenda do governo" e "alertar à população como é importante termos governos municipais e estaduais sérios e que busquem o equilibrio fiscal".

\section{Um outro quarto poder}

Isso nos conduz à nossa última questão: de que maneira a imprensa brasileira se relaciona com o sistema de divisão de poderes como um todo e com os três poderes constitucionais em particular? Nossa hipótese é que a imprensa brasileira se define, tal como a americana, como um "quarto poder", mas concebe o seu papel político em termos muito mais ativos do que esta. Mais do que meramente contribuir para o equilibrio entre os poderes constituídos. a imprensa brasileira tem reivindicado autoridade para. em casos de disputas entre eles, intervir em favor de um poder contra o outro, a fim de preservar a ordem pública. Por detrás do discurso "americano" sobre o quarto poder, e de modo nâo necessariamente consciente, esconde-se um modelo inteiramente distinto acerca do seu propósito, o modelo caracteristicamente brasileiro do "poder moderador".

Tal afirmação se presta a diversas interpretações, muitas das quais totalmente distintas da adotada por este artigo. Faz-se necessário, então, uma pausa estratégica para esclarecermos o sentido da afirmação acima. Para começar, não estou sugerindo aqui que a definição, pela imprensa brasileira, do seu papel político nos termos de um "poder moderador" se faça de modo tão ativo e consciente como na Constituição imperial ou entre os militares no periodo entre 1946 e 1964 . Ao invés disso, sustento que a idéia de "poder moderador" constitui uma resposta à histórica ambivalência que tem caracterizado a relação da cultura política brasileira com o modelo da divisão de poderes. Engenhosamente, ela permite conciliar a adesão formal ao sistema da divisão de poderes - uma exigência da ordem politica civilizada - como 
seu descumprimento na prática, através do apelo a forças que pairam acima do sistema.

Menos ainda estou afirma9ndo que essa pretensão da imprensa brasileira contemporânea tem sido reconhecida como legítima por amplos setores da sociedade brasileira e, em particular, pelos três poderes constitucionais. Na prática, os setores políticos têm tendido a emprestar maior ou menor legitimidade à intervenção da imprensa na política na medida dos seus interesses particulares. Quando a participação ativa da imprensa na defesa de um determinado ponto de vista coincide com a perspectiva do agente político, ela é saudada como uma contribuição para a democracia; quando isto não acontece, ela é denunciada como um abuso do direito à liberdade de expressão.

Para melhor ilustrar o problema, passo a fazer algumas considerações sobre as complexas relações que o jornalismo brasileiro tem estabelecido com os três poderes constitucionais no Brasil. Comecemos pelas relações da imprensa com o Poder Executivo.

"Governismo" é por certo a característica mais frequentemente apontada (e criticada) na relação que imprensa estabelece com o Poder Executivo no Brasil, uma relação que foi qualificada, em matéria da revista Imprensa como "jornalismo chapa-branca". Para que não fiquem dúvidas de que não se trata de mero choro de descontentes e derrotados, vale reproduzir a declaração de Júlio César Ferreira de Mesquita, diretor responsável d' O Estado de São Paulo - um jornal definitivamente insuspeito de oposicionismo ao governo FHC reproduzida nesta mesma matéria: "A imprensa se acomodou no oficialismo das informações" (apud Bresser, 1996: 27). Se tudo isso parecer insuficiente, não custa citar um trecho de uma conversa entre o presidente Fernando Henrique e o ex-presidente do BNDES, Mendonça de Barros que, tendo sido "grampeada", foi tornada pública pelos meios de comunicação do país. A conversa gira em torno do leilão de privatização das empresas de telecomunicações:

Mendonça de Barros: E no fundo a imprensa está muito favorável, os editoriais, tudo.

Fernando Henrique: Está demais. Exagerando até... (Risos) ${ }^{6}$

A despeito dessas evidências, o alinhamento da imprensa brasileira com o governo não tem sido nem de longe consistente e sistemático ao longo desta década. Se é verdade que a imprensa brasileira tem cerrado fileiras em torno do governo $\mathrm{FHC}$, o caso Collor ilustra um 
posicionamento oposto: um engajamento aberto da imprensa na oposição ao presidente. visando a sua deposição (Fausto Neto. 1994a: Fausto Neto. 1994b: Lattman-Weltman, Carneiro \& Ramos. 1994. José, 1996).

O governismo e o oposicionismo podem explicar a atuação das instituições jornalísticas brasileiras em momentos específicos da nossa história recente, mas não permitem dar conta do problema como um todo. A questão que importa responder é: que fundamento comum permite à imprensa brasileira reivindicar coerência enquanto adota posições diametralmente opostas em relação ao executivo? A resposta que nos parece mais plausivel é: o compromisso da imprensa brasileira conn a defesa da ordem pública em geral, e da democracia em particular. Esse compromisso é explicitamente reivindicado por jornais como a Folha de Sáo Paulo, a qual, en seu Novo Manual de Redação alirma que "A Fillha realiza campanha em situação especial, quando dirige seus esforços para promover determinada causa que julgue ser do interesse público" (Novo Manual da Redação - Folha de S. Paulo: 1992: 14).

Na prática, o batismo de fogo da Folha de São Paulo como promotora de campanhas civicas se deu na campanha pelas Diretas-Já em 1984 (Silva, 1988). no que ela foi seguida por boa parte da imprensa brasileira, ainda que em muitos casos tardiamente (Guimarães \& Amaral, 1988; Tosi, 1995). Seja como for, a imprensa brasileira atuou decisivamente como fiadora da transição do regime militar para a "Nova República", engajando-se na campanha de Tancredo Neves nas elcições indiretas para a Presidência e garantindo a mobilização popular em favor do novo regime em momentons difĭceis, em especial no período que se estendeu da internaçào hospitalar do presidente eleito . horas antes da sun possé - até a sua morte (Fausto Neto, 1989). A cobertuia jornalística não se limitou, porém, a garantir a democracia contra um retrocesso aucoritário: a Rede Globo interviu decisivamente no processo que determinou quem deveria ser o sucessor de Tancredo Neves. Uına vez que Tancredo ainda não havia tomado posse, pairàa uma dúvida sobre quem deveria assumir a Presidência: o vice-presidente eleito Jcisé Sarney ou Ulysses Guimarães, o presidente da Câmara dos Deputados e primeiro na ordem constitucional de sucessão. A Globo convocou inúmeros especialistas em direito constitucional para apoiar a tese da vice-presidência, e colaborou decisivamente para a formação de $t$ :m consenso em torno do nome de Sarney (Guimarães e Amaral, 1988). 
A despeito do discurso oficial do jornalismo brasileiro, o seu compromisso com o interesse público é entendido muito menos com base no respeito às normas da "objetividade" jornalística que nos termos de uma responsabilidade com a estabilidade política e econômica. Um exemplo disto é a recente polêmica motivada por críticas do presidente Fernando Henrique ao comportamento da imprensa brasileira, seguidas pela sugestão de que deveriam ser criados mecanismos de regulamentação externa para coibir abusos na sua atuação. Tais declarações motivaram reações indignadas por parte de diversos jornalistas e instituições, das quais uma nos interessa em particular: trata-se de um editorial da revista Imprensa denominado "O presidente e a imprensa". O que mais chama a atenção neste editorial é o fato de não mencionar em momento algum o argumento da objetividade - algo como "noticiamos apenas os fatos" - para contestar as críticas do presidente. Ao invés disso, o editorial considera as críticas de FHC como ingratidão de um presidente que não soube reconhecer o apoio dispensado pela imprensa ao seu governo. E, dado importante, em momento algum considera este apoio problemático. Isto é ilustrado de modo muito claro pela seguinte afirmação: "Quando o presidente começou a se empenhar na aprovação do projeto de reeleição, do qual ele seria o principal beneficiário, a imprensa concordava que um país que queria perfilar-se entre os de primeiro mundo deveria adotar a reeleição". Ou ainda: "Nesses e em outros casos a imprensa pesou bem o que deveria ou não publicar e optou por não publicar fatos que pudessem atrapaIhar a caminhada do presidente rumo ao segundo mandato". De onde se segue a conclusão: "Por isso, IMPRENSA acredita que não procedem as queixas do presidente Fernando Henrique a uma imprensa que se manteve sempre ao seu lado, poupando-o de críticas e apoiando-o nos momentos mais delicados do seu governo".

Pode-se sugerir que, em termos genéricos, a relação da imprensa com o Executivo se faz segundo a lógica da "autoridade", enquanto a relação com o Legislativo segue a lógica da "política" 7 . No primeiro caso a ênfase recai principalmente sobre questões relativas ao interesse da Nação como um todo e à competência técnica dos agentes encarregados de lidar com elas; no segundo, têm-se em vista os interesses particulares dos (ou representados pelos) agentes envolvidos, e do processo de barganha que se estabelece em torno deles. Num ambiente cultural que subordina o interesse individual à ordem coletiva e que olha com profunda desconfiança o processo de condução negociada da produção de verdades, é razoável supor então que, como regra ge- 
ral. a cobertura jornalistica do Legislativo tenda a retratá-lo em termos muito menos favoráveis que ao Executivo.

O título de capa da revista Veja citado na abertura deste artigo, "Por que o Brasil desconfia dos políticos", ilustra isso claramente. Embora o título se refira a uma desconfiança em relação aos políticos em geral, é especificamente dos congressistas que tratam as duas matérias a ele relacionadas. As duas matérias se apresentam como uma prestação de serviço aos eleitores: na véspera da eleição, trata-se de ajudá-lo a separar o joio do trigo no Congresso. A matéria principal, "Atenção com eles", com seis páginas, trata basicamente do joio: congressistas ausentes, vira-casacas, processados pela Justiça. "Turma da eficiência", com duas páginas, refere-se ao trigo.

Além da ampla predominância de aspectos negativos sobre os positivos na avaliação da atuação dos congressistas, duas outras caracteristicas dessas matérias merecem ser destacadas. A primeira se refere aos critérios fundamentais da avaliação: os deputados não são julgados tanto por suas idéias ou princípios, mas pela sua adequação a padrões "técnicos" de avaliação, relativos à sua eficiência e conformidade a parâmetros éticos. Assim, o partido com mais nomes citados na lista "Os bons da Câmara" é o PT (9) em comparação com os 8 nomes do PSDB e 6 do PFL - ambos com bancadas muito maiores do que a do PT. Por outro lado, dentre os 46 deputados da lista "Produção zero" (deputados que não apresentaram projetos de lei ou emendas constitucionais), 14 pertencem ao PFL, 9 ao PSDB e nenhum ao PT. Esses dados são tâo mais impressionantes na medida em que o PFL e o PSDB foram os principais sustentáculos das reformas constitucionais que Veja consistentemente apoiou no primeiro mandato de FHC, e o PT foi a principal força de oposição a elas. A segunda característica diz respeito ao próprio propósito da avaliação: trata-se explicitamente de orientar o processo de decisão do voto dos eleitores. Dessa forma, a revista Veja faz mais do que meramente falar dos congressistas ou do Legislativo como um todo; ela reivindica para si própria a autoridade para não somente avaliar "objetivamente" o desempenho dos congressistas, como também fornecer uma indicação "independente" de voto para os eleitores.

Seja como for: as duas matérias em questão dispensam ao Congresso Nacional uma atenção e um nivel de respeito inusitadamente altos, se considerarmos o conjunto da cobertura dedicada a ele por Veja e pela imprensa brasileira como um todo. Os estudos brasileiros que tratam do assunto têm destacado que, de um modo geral, a cober- 
tura dedicada ao Legislativo no Brasil é reduzida e acentua desproporcionalmente escândalos e aspectos ridículos da sua atuação (Chaia, 1995; Porto, 1997). Em grande medida como reação a isso, discute-se no Congresso a aprovação de uma Lei da Imprensa, destinada a prevenir "abusos no exercício da Liberdade de manifestação do pensamento e informação" (Art. 12) ou, dito de modo mais claro, a limitar a margem de manobra política da imprensa.

A relação do jornalismo brasileiro com o Judiciário é tão ou mais problemática que a relação com o Legislativo. Conforme observam Fausto Neto, Castro e Lucas (1995), a imprensa carioca não se limita, em sua cobertura da violência e do crime ao papel de relatar os acontecimentos, mas assume o papel de um tribunal, que "julga, acusa, sentencia e absolve" (1995:126). A adoção de um papel tão ativo, que se confronta claramente com os princípios da objetividade, se explica em parte pelo modo como a imprensa avalia a Justiça brasileira: lenta, corrompida, parcial. Zuenir Ventura (1999), por exemplo, define a Justiça nos seguintes termos: "Zelosa em obedecer à letra da lei, ela 48 respeita mais o que está escrito do que o de direito, sobretudo dos mais fracos".

Em face da ineficiência da Justiça, os jornalistas brasileiros se vêem tentados a realizar simbolicamente a justiça que ela não é capaz de fazer. Isso talvez ajude a entender por que a imprensa brasileira seja frequentemente tão rápida e definitiva na determinação da culpa dos crimes, e tão dura no tratamento dispensado a aqueles a quem considera culpados. $O$ fato de por vezes, isto implicar em um enorme dano à vida de cidadãos inocentes não é (ou pelo menos não tem sido até o presente) uma razão forte o suficiente para forçar uma mudança no modo como os jornalistas tratam o crime e/ou os (supostos) criminosos. A atenção dispensada pelos jornalistas a casos como o da "Escola Base" - tornado um paradigma dos abusos da imprensa no país não impediu que em inúmeras ocasiões posteriores jornalistas tenham se adiantado à Justiça na identificação categórica de culpados (Ribeiro, 1995; Carmona, Duarte e Maciel, 1998).

Tal como acontece com o Legislativo, também o Judiciário brasileiro tem reagido ao que considera ser um desafio ilegítimo à sua autoridade institucional. O exemplo mais recente disso é a polêmica que se estabeleceu entre membros do Judiciário e da imprensa em torno da proposta da comissão que estuda a reforma do Código Penal de caracterizar como crime de coação indireta do processo judicial a publi- 
cação de notícias que. antes da decisão judicial definitiva sobre um assunto, contribuam para influenciar juiz ou testemunhas. com pena de três meses a um ano de prisão.

\section{Conclusão}

Ao longo deste texto, procurei explorar um velho tema - a influência do modelo americano do jornalismo "independente" sobre o jornalismo brasileiro - por um caminho diferente daquele que é normalmente percorrido pelos estudiosos do assunto. Ao invés de julgar o modelo brasileiro pela sua maior ou menor proximidade em relação ao americano, sugeri que este último era fruto de um contexto político-cultural inteiramente distinto do brasileiro e que, portanto, não seria plausivel que, na prática, o jornalismo realizado no Brasil se assemelhasse ao americano. Deste ponto de vista. a questão a investigar seria outra: de que maneira o jornalismo brasileiro reinterpreta, à luz dos códigos da cultura política local o modelo "oficial" do jornalismo independente?

Em particular, sugeri que uma série de características fundamentais do modelo de jornalismo "independente" - o compromisso com os fatos, a defesa do interesse público e a objetividade jornalística, a ênfase em individuos e acontecimentos individuais. o destaque dado ao repórter individual na produção da notícia, a eleição do cidadão individual como interlocutor fundamental do jornalista, e a auto-caracterização deste último com um representante dos interesses dos cidadãos frente às instituições - somente fazem sentido no âmbito de uma cultura individualista e na qual exista um amplo acordo em torno de um conjunto de verdades fundamentais.

Uma atenção especial foi dispensada à relação entre a imprensa e os três poderes constitucionais no Brasil. Procurei demonstrar que o modelo americano da imprensa como um "Quarto Poder" é, em nosso pais, objeto de uma releitura bastante radical. Enquanto nos Estados Unidos, a idéia de "Quarto Poder" traduz um compromisso da imprensa com o sistema de divisão de poderes como um todo (e com a conservação do equilíbrio entre os poderes em particular), no Brasil, ela apela de alguma maneira para uma tradição brasileira, e totalmente distinta de Quarto Poder: o Poder Moderador. Tal como o fizeram em tempos passados o Imperador e os militares, a imprensa reivindica hoje exercer o papel de árbitro das disputas entre os poderes constituidos, decidindo sempre em favor do "Bem Comum". O que não quer 
dizer que tais pretensões sejam amplamente reconhecidas pelos demais agentes sociais: ao reivindicar para si o exercício de prerrogativas que outras instituições consideram como suas, a imprensa brasileira se sujeita a uma crescente hostilidade por parte dos seus membros: as propostas da Lei de Imprensa, da reforma do Código Penal e as recentes declarações de Fernando Henrique acerca da imprensa brasileira são apenas os primeiros rounds de uma disputa que tem tudo para se tornar tanto intensa quanto duradoura.

\section{Bibliografia}

ARAGÃO, Murilo de (1998). Cabe à imprensa insistir na necessidade das reformas. Imprensa n ${ }^{\circ} 134$, nov. 1998, p. 20.

BAQUERO, Marcello (1996). A desilusão democrática: um estudo longitudinal de cultura política. Comunicação \& Política v. III, no 3, p. 48-72.

BARBOSA, Lívia (1992). O jeitinho brasileiro: a arte de de ser mais igual que os outros. Rio de Janeiro: Campus.

BARBOSA, Lívia (1996). Meritocracia à brasileira: o que é desempenho no Brasil. Revista do Serviço Público. Ano 47, vol. 120, n 3, p. 59-102)

BELLAH, Robert N (1967). "Civil religion in America". Daedalus, 96 (3), p. 1-21.

BELLAH, Robert N.; MADSEN, Richard; SULLIVAN, William M.; Swidler, Ann \& TIPTON, Steven M. (1996). Habits of the Heart: Individualism and Commitment in American Life. Berkeley: University of California Press.

BRESSER, Deborah (1996). Com quem está preso o rabo da imprensa? Imprensa ${ }^{\circ}$ 101, fev. 1996, p. 24-29.

CAMPBELL, Richard (1991). 60 Minutes and the News: a Mythology for Middle America. Urbana and Chicago: University of Chicago Press.

CARDOSO, Adalberto M. Jornalistas (1995): ética e democracia no exercício da profissão (um survey entre jornalistas brasileiros). Novos Estudos CEBRAP n ${ }^{\circ} 42$, p. 130-140.

CARMONA, Arnaldo; DUARTE, Roberto e MACIEL, Luiz Antonio (1998). Um rastro de vítimas. Imprensa $n^{\circ} 128$, São Paulo, maio de 1998, p. 20-30. 
CAREY, James W. (1986) The Dark Continent of American Journalism. In MANOFF, Robert Karl \& SCHUDSON, Michael. Reading the News. New York: Pantheon Books, p.146196.

CARVALHO, José Murilo de (1977). "As forças armadas na Primeira República: o poder desestabilizador". In FAUSTO, Bóris (org.) História Geral da Civilização Brasileira - Tomo III: o Brasil Republicano. Rio de Janeiro, Difel, p. 181-234.

CARVALHO, José Murilo de (1987). Os Bestializados: o Rio de Janeiro e a Repuiblica que não foi. São Paulo: Companhia das Letras.

CARVALHO, José Murilo de (1990). A Formação das Almas: o imaginário da República no Brasil. São Paulo: Companhia das Letras.

CARVALHO, Olavo de (1999). A história oficial de 1964. O Globo, 19/01/1999, p. 7.

CASTRO, Celso (1995). Os Militares e a República: um estudo sobre cultura e ação politica. Rio de Janeiro.

CHAIA, Vera (1995). A Imprensa e a Câmara Municipal de São Paulo. Revista de Ciências Humanas v. 13, n” 17 el8, p. 67-81, Florianópolis.

CHALABY, Jean K (1996). Journalism as an Anglo-American Invention: A Comparison of the Development of French and Anglo-American Journalism, 1830s-1920s. European Journal of Communication, vol. 11 (3). p. 303-326.

COELHO, Edmundo Campos (1976). Em busca de identidade: o exército de identidade. O exércilo e a política na sociedade brasileira. Rio de Janeiro: Forense-Universitária.

COOK, Timothy E (1998). Government with the News: The News Media as a Political Institution. Chicago: University of Chicago Press.

COSTA, Sylvio \& BRENER, Jaime (1997). Coronelismo eletrônico: o governo Fernando Henrique e o novo capilulo de uma velha história. Comunicação \& Política, vol. IV, n. 2, nova série.

Da MATTA, Roberto (1979). Camavais, malandros e heróis. Rio de Janeiro, Zahar.

Da MATTA, Roberto (1997). A casa e a rua: espaço, cidadania, muther e morte no Brasil. Rio de Janeiro: Rocco, $5^{\mathrm{a}} \mathrm{ed}$. 
DONSBACH, Wolfgang \& PATTERSON, Thomas E (1992). “Journalists' Role and Newsroom Practices: a Cross-National Comparision. Paper presented in the Joint Session "Politics and the news in democracies" of the International Communication Association (ICA) and the World Association for Public Opinion Research (WAPOR), 42nd Conference of the International Communication Association, Miami, FL, May 21 $25,1992$.

DUMONT, Louis (1966). Homo hierarchicus: le système de castes et ses implications. Paris: Gallimard.

DUMONT, Louis (1985). O individualismo: uma perspectiva antropológica da ideologia moderna. Rio de Janeiro: Rocco.

ESSER, Frank (1998). Specialists vs All-rounders: Opposing Principles of Organizing Work in Anglo-Saxon and German Newsrooms. Paper presented at the $48^{\text {ih }}$ Annual Conference of the International Communication Association. Jerusalem, Israel, 20-24 July, 1998.

52 ETTEMA, James S. \& GLASSER, Theodore (1998). Custodians of Conscience: Investigative Journalism and Public Virtue. New York: Columbia University Press.

FAUSTO NETO, Antônio (1989). O corpo falado (a doença e morte de Tancredo Neves nas revistas semanais brasileiras). Belo Horizonte: PUC-MG/FUMARC, $2^{\mathrm{a}}$ ed.

FAUSTO NETO, Antônio (1994a). "Vozes do impeachment" in MATOS, Heloiza (org). Midia, eleições e democracia. São Paulo: Scritta, p. 159-189.

FAUSTO NETO, Antônio (1994b). “A sentença dos media: o discurso antecipatório do impeachment de Collor" in FAUSTO NETO, Antônio, BRAGA, José Luiz \& PORTO, Sérgio Dayrell (org.) Brasil: comunicação, cultura \& política. Rio de Janeiro: Diadorim, p. 328-355.

FAUSTO NETO, Antônio; CASTRO, Paulo César \& LUCAS, Ricardo J. L (1995). "Mídia-tribunal. A construção discursiva da violência: o caso do Rio de Janeiro". Comunicação \& Política, n.s., v. $1, \mathrm{n}^{\circ} 2$, p. 107-140.

FISHER, Louis (1989). Separation of Powers in America: Theory and Practice. In UTLEY, Robert L. (Ed.) Principles of the Constitutional Order: The Ratification Debates. Laham: University Press of America, p. 131-149. 
FISHMAN, Mark (1980). Manufacturing the News. Austin: University of Texas Press.

GANS, Herbert (1979). Deciding what's News: a Study of CBS Evening News, NBC Nightly News, Newsweek and Time. New York: Pantheon Books.

GEERTZ,Clifford. O saber local: novos ensaios em antropologia interpretativa. Petrópolis: Vozes, 1998.

GENRO FILHO, Adelmo (1989). O segredo da pirâmide: para uma teoria marxista do jornalismo. Porto Alegre: Ortiz.

GITLIN, Todd (1980). The Whole World is Watching: Mass Media in the Making \& Unmaking of the New Left. Berkeley: University of California Press.

GUIMARÃES, César \& AMARAL, Roberto (1988). "Brazilian Television: a Rapid Conversion to the New Order". in FOX, Elizabeth (ed.). Media and Politics in Latin America: the Struggle for Democracy. London: Sage, p. 125-137.

HALLIN, Daniel (1994). We keep America on top of the World: Television and the Public Sphere. London \& New York: Routedge.

HALLIN, Daniel (1996). "Dos instituciones un camino: a televisão e o Estado na eleição de 1994 no México" in Comunicação \& Politica v. 111, n², p. 72-93.

HALLIN, Daniel C. \& MANCINI, Paolo (1984). "Speaking of the President: Political Structure and Representational Form in U.S. and Italian Television News". Theory and Society, 13, p. 829850 .

IMPRENSA (1998). O presidente e a imprensa. $\mathrm{n}^{\circ}$ 135, p. 12.

JAGUARIBE, Hélio (1999). Ditadura do Congresso; entrevista [com] Ricardo Galuppo. Veja, São Paulo, v. 32, nº 5, p. 11-13, 3 fev. 1999.

JOSÉ, Emiliano (1996). Imprensa e poder: ligações perigosas. Salvador/São Paulo: EDUFBA/Hucitec.

LATTMAN-WELTMAN, Fernando; CARNEIRO, José Alan Dias \& RAMOS, Plinio de Abreu. A imprensa faz e desfaz um presidente. Rio de Janeiro: Nova Fronteira, 1994. 
LIMA, Roberto Kant de (1994). Conciliação e julgamento, negotiation e trial: a produção da ordem em uma perspectiva comparada (Brasil/EUA) In GIUCCI, Guillermo e DAVID, Maurício Dias (org.): Brasil-EUA: antigas e novas perspectivas sobre sociedade e cultura.

LIMA, Venício A. de (1993). "Notas preliminares sobre o jornalismo da Rede Globo: um "estudo de caso" sobre o DF-TV. Texto apresentado por ocasião do XXI Encontro Anual da Associação Nacional de Programas de pós graduação em Ciências Sociais (ANPOCS), realizada em Caxambu (MG), entre os dias 21 e 25 de outubro de 1993.

MANCINI, Paolo (1991). The public sphere and the use of news in a 'coalition' system of government. In DAHLGREN, Peter \& SPARKS, Colin. Communication and citizenship: journalism and the public sphere. London and New York: Routledge, p. 135-154.

MEDEIROS, Borges de (1933). O Poder Moderador na República Presidencial (Um ante-projecto da Constituição Brasileira). Recife: Edição da S.A. Diário de Pernambuco.

MIGUEL, Luís Felipe (1996). "Sentidos do passado: nação, tradição e história na campanha eletrônica para o plebiscito de 21 de abril". in Comunicação \& Política v. III, n² 2, p. 126-145.

MOTTER, Paulino (1994). O uso político das concessões das emissoras de rádio e televisão no governo Sarney. Comunicação \& Politica, nova série, vol. 1, $\mathrm{n}^{\circ} 1,89-116$.

NERONE, John C. "A Local History of the Early U.S. Press: Cincinnati, 1793-1848. In SOLOMON, William S. \& McCHESNEY, Robert W. (eds.). Minneapolis: University of Minnesota Press, 1993, p. 38-65.

ORTIZ, Renato (1988). A moderna tradição brasileira: cultura brasileira e indústria cultural. São Paulo: Brasiliense.

PORTO, Mauro Pereira (1997). "Os mídia e a legitimidade da democracia no Brasil". Midia e cultura. Rio de Janeiro: Diadorim.

RIBEIRO, Alex (1995). Caso Escola Base: os abusos da imprensa. São Paulo: Ática

RIBEIRO, Jorge Claudio (1994). Sempre alerta: condições e contradições do trabalho jornalístico. São Paulo: Olho d'águal Brasiliense. 
SCHUDSON, Michael (1978). Discovering the News: a Social History of American Newspapers. New York: Basic Books.

SCHUDSON, Michael (1982). "The Politics of Narrative Form: the Emergence of News Conventions in Print and Television". Daedalus 111 (4), p. 97-112.

SCHUDSON, Michael (1993). Watergate in American Memory: How we Remember, Forget, and Reconstruct the Past. New York: Basic Books, Paperback ed.

SILVA, Carlos Eduardo Lins da (1988). Mil dias: os bastidores da revolução em um grande jornal. São Paulo: Trajetória cultural.

SILVA, Carlos Eduardo Lins da (1991). O adiantado da hora: a influência americana sobre o jornalismo brasileiro. São Paulo: Summus.

SKIDMORE, Thomas E (1996). Brasil: de Getúlio a Castelo. Rio de Janeiro: Paz e Terra, $10^{\text {a }}$ ed.

SOLOSKI, John (1993). "O jornalismo e o profissionalismo: alguns constrangimentos no trabalho jornalístico". In TRAQUINA, Nélson (org.) Jornalismo: questoes, teorias e "estorias". Lisboa: Vega, p. 91-100.

TASCHNER, Gisela (1992). Folhas ao vento: análise de um conglomerado jornalístico no Brasil. Rio de Janeiro: Paz e Terra.

TOSI, Alberto (1995). A massa na praça: mobilização e conflito na campanha das "Diretas Já". Comunicação \& Política, vol. 1, n 3, p. 163-178.

TUCHMAN, Gaye (1993). "A objectividade como ritual estratégico: uma análise das noções de objetividade dos jornalistas". In TRAQUINA, Nélson (org.) Jornalismo: questoes, teorias $e$ "estorias". Lisboa: Vega, p. 61-73.

TUCHMAN, Gaye (1978). Making News: a Study in the Construction of Reality. New York: The Free Press.

WAISBORD, Silvio (1996a). Investigative Journalism and Political Accountability in South American Democracies. Critical Studies in Mass Communication 13, p. 343-363.

WAISBORD, Silvio (1996b). "Contando histórias de corrupção: narrativa de telenovela e moralidade populista no Caso Collorgate" in Comunicação \& Polífica v. Ill, n², p. 94-111. 
WAISBORD, Silvio (1997). Can Investigative Reporting Tell the Truth? The Modernity of Journalism in Latin America. Paper presented at the session "New Profiles in Latin American Journalism", conference of the International Communication Association, Montreal, May 1997.

VENTURA, Zuenir. Um bloco de sujo.O Globo 13/02/99 Caderno B, p.

ZELIZER, Barbie (1992). Covering the Body: the Kennedy Assassination, the Media, and the Shaping of Collective Memory. Chicago and London: The University of Chicago Press.

\section{Notas}

1 Doutor pela ECO/UFRJ e professor da UFF. Agradeço a Silvio, Waisbord, Mauro Porto e Fernando Azevedo pelas opiniões e críticas manifestadas acerca de algumas idéias exploradas neste artigo.

2 Sobre o fenômeno do "coronelismo eletrônico", isto é, o uso da concessão de estações de rádio e televisão como instrumento de barganha política pelos governos Sarney e FHC ver, respectivamente, Motter (1994) e Costa e Brenner (1997).

3 A atribuição aos militares de um poder moderador em situações de crise ainda não perdeu, porém, todo o seu prestígio. Para um exemplo recente, ver Carvalho (1999)

4 O incômodo manifestado em relação ao sistema de divisão de poderes não é privilégio dos setores extremistas da sociedade brasileira, mas pode ser notado também em intelectuais tradicionalmente identificados com a social-democracia. São bastante ilustrativas, a este respeito, as observações de Hélio Jaguaribe (1999) em entrevista à revista Veja. Por exemplo: "Temos um sistema presidencialista enfraquecido por um Congresso que funciona mal, que não tem coerência, mas tem um enorme poder. Esse sistema é inviável porque gera conflito entre o Congresso e o governo". Jaguaribe afirma também que é preciso haver "um regime institucional que obrigue os parlamentares a compor uma maioria estável em torno de um programa de governo" e sugere, para tal, a criação de um mecanismo de dissolução do Congresso sempre que tal maioria se mostre inviável. 
5 Não estou negando aqui que o modo de atuação da imprensa brasileira seja, em diversos pontos, profundamente hostil à democracia, principalmente no que se refere à democratização da informação como condição da liberdade de escolha. Apenas discordo que tenha na atitude adversária com relação à democracia um princípio de atuação.

6 Trecho transcrito da versão online da revista Época. Http:// www.epoca.com.br

7 Tal distinção se baseia em um artigo de Daniel Hallin (1996) que analisa a cultura política e o telejornalismo mexicanos. 
